\title{
Financing climate change in the conditions of the Slovak agricultural sector
}

\author{
Ivan Holúbek ${ }^{1, *}$, Marián Tóth ${ }^{1}$, Tomáš Rábek $^{1}$, and Johana Jakabovičová1 \\ ${ }^{1}$ Slovak University of Agriculture in Nitra, Faculty of Economics and Management, Department of \\ Finance, Tr. Andreja Hlinku 2, 94976 Nitra, Slovak Republic
}

\begin{abstract}
Research background: Globalization is a powerful engine of structural changes in national, regional and global economies. Except for positive economic effects, globalization also has negative effects. One of them is the deterioration of the global environmental situation and the ongoing global climate change.

Purpose of the article: The paper focuses on the current global financing trends to mitigate the effects of climate change. Generally financial funds come from international, national and regional actors. Governments have a range of funding mechanisms and resources at their disposal. Within the EU, these are the Structural Funds, investment funds and the financing from European Investment Bank. At the national level, it is financial assistance from state budgets and local government budgets.

Methods: The paper provides literature review of the possibilities of financing climate change at the national and international level and, using analysis and synthesis, points to future trends and sources of financing climate change. We also analyse the proposal of Common agricultural policy 2021-2027 and effects on Slovak agriculture. European Commission wants member states to use up to $40 \%$ of the budget for environmental goods and climate change. Slovakia might have problems to spend the allocation due to the fact, that most of the money will be voluntary schemes. Farmers will have the option to participate.

Findings \& Value added: Agriculture is seriously exposed to the adverse effects of climate change as agricultural activities are directly depending on climate conditions. The article analyses in detail the possibilities and sources of financing adaptation measures in the Slovak agricultural sector.
\end{abstract}

Keywords: agriculture; climate change; adaptation; financing; common EU agricultural policy

JEL Classification: $Q 14 ; Q 28 ; Q 54$

\section{Introduction}

\footnotetext{
*Corresponding author: ivan.holubek@uniag.sk
} 
Since the beginning of the 1990s [1], there have been changes in the economies of developed countries, which are often compared with the significance of the industrial revolution. These changes are associated with the introduction of new technologies whose impact on the reproductive process and economy is so significant that economists have begun to associate knowledge and innovation as specific factors of production to traditional factors of production - labor, land and capital. Globalization is clearly proving to be a powerful engine of structural change in national, regional and global economies. In addition to its positive effects, globalization also has negative effects [2]. In this context, we can point to the economic crisis, which includes the financial crisis and the unemployment crisis. The second adverse effect of globalization is the deterioration of the environmental position. Rich countries have the highest share of environmental pollution. Another negative effect of globalization is the widening of the gap between rich and poor countries. Environmental policy is made in a context of both market failure and government failure. On the one hand, leaving environmental protection to the free market, relying on notions of corporate social responsibility and altruistic consumer and shareholder preferences, will not deliver optimal results. On the other hand, nationalizing the delivery of environmental protection is likely to fail because nation states rarely have the depth and quality of information required to instruct all the relevant agents to make appropriate decisions [3].

\section{Material and Methods}

At the beginning, it is important to note that the researched issues are current and knowledge in this area is just beginning to be created. Only now is the public and private sector beginning to create the conditions and funding schemes for adaptation measures to mitigate the effects of climate change. The methodological apparatus, methodology and methods of the artcicle follow the identification, analysis and implementation of preventive adaptation measures in the agricultural sector in terms of adverse effects of climate change, which can represent significant economic and social costs. The paper provides primarily literature review of the possibilities of financing climate change at the national and international level and, using analysis, synthesis, induction and deduction points to future trends and sources of financing climate change. We also analyse the proposal of Common agricultural policy 2021-2027 and effects on Slovak agriculture.

\section{Results and discussion}

\subsection{Globalization and climate change - theoretical background and definitions}

The 2030 Agenda for Sustainable Development, adopted by all UN Member States in 2015, provides a common plan for peace and prosperity for the people and the planet, now and in the future. At its heart are 17 sustainable development goals, which are an urgent call for action by all countries, both developed and developing, in the framework of the Global Partnership. Recognizing that ending poverty and other deprivation must go hand in hand with strategies that improve health and education, reduce inequality and stimulate economic growth - all in tackling climate change and protecting our oceans and forests. The Sustainable Development Goals (SDGs) are specified across three dimensions: society, environment and economy. The SDGs (2012) are a set of seventeen goals on poverty, environment, social equality and prosperity and 169 goals that the member states of the United Nations (UN) have committed to achieve by 2030 . These seventeen goals are the continuators of the Millennium Development Goals (MDGs) that were created in 2000 with the aim of alleviating the social problems of underdeveloped countries. In the late 1980s, The 
Brundtland Commission linked sustainable to systematic or long-term use of natural resources available for future generations. [4]. The Sustainable Development Goals (SDGs) have the potential to become a strong political vision that can support the urgently needed global transition to shared and lasting prosperity. In December 2014, the UN SecretaryGeneral published his report on the Sustainable Development Goals. The ultimate goals adopted by the UN General Assembly in September 2015 may fall short of expectations due to what we call the cockpit illusion that top-down governance alone can only solve global problems on governments and intergovernmental organizations. Given the limited effectiveness of intergovernmental efforts and issues related to the ability of national governments to influence change, new actors of change, such as businesses, cities and civil society, need to be further mobilized for sustainable development goals. Forecasts of climate change suggest that the extent and speed of change caused by increasing concentrations of greenhouse gases in the atmosphere are unprecedented in human history and will significantly and in many cases dramatically change the availability and quality of natural resources. Climate extremes cause widespread economic damage each year and risks are expected to increase with continued socio-economic development and climate change. Risk is usually presented as the probability of the occurrence of dangerous events or trends multiplied by the impact, if such events or trends occur. The risk is caused by the interaction of danger, exposure and vulnerability. Exposure usually refers to people, livelihoods, resources, infrastructure and economic, social or cultural assets in places and environments that could be adversely affected [5]. Degrowth has become a dazzlingterm within critiques of capitalism. The concept challenges the assumption that economic growth leaves people better off and happy. The production of goods and services issupposed to improve living conditions: the ongoing growth of production and consumption is assumed to raise living standards and well-being. The ecological crisis tells us that this story of social progressthrough economic growth is highly questionable.Degrowth is one possible answer to the problems created not onlyby the overexploitation of natural resources Degrowth has become a dazzlingterm within critiques of capitalism. The concept challenges the assumption that economic growth leavespeople better off and happy. The production of goods and services is supposed to improve living conditions: the ongoing growth of production and consumption is assumed to raise living standards and well-being. The ecological crisis tells us that this story of social progress through economic growth is highly questionable.Degrowth is one possible answer to the problems created not onlyby the overexploitation of natural resources [6]. Governments in countries across the world increasingly adopt the "green growth"discourse to underline and promote their ambition forthe greening of their economies. The central tenet of this narrative is the economic opportunities rather than challenges arising from thepursuit of environmental sustainability. While definitions of green growth abound, we here follow the often cited OECD de-finition of green growth as"fostering economic growth and development while ensuring that natural assets continue to provide the resources and environmental services on which our well-being relies". Consequently, green growth is suggested to be a key element inachieving sustainable development: on the one hand, protecting the environment, while on the other hand allowing economic growth [7].

Climate change is the sum of climate change (changes over a period of 30 years or more), which is reflected in an increase in average global temperature, an increase (sometimes a decrease) in local average temperature, an increase (sometimes a decrease) in average precipitation activity, an increase (sometimes a decrease) wind, rising temperature, precipitation, storm and vapor extremes and rising temperature differences during the day. From the point of view of climatology, the Hurbanovo meteorological station represents one of the most conservative stations located practically in unchanged conditions (buildings, surroundings). The average annual air temperatures from Hurbanovo show an increasing 
tendency using a linear trend (Fig. 1). The change in such a statement represents an increase of $+1.6^{\circ} \mathrm{C}$ from 1901 to 2012 (SHMU, SK).

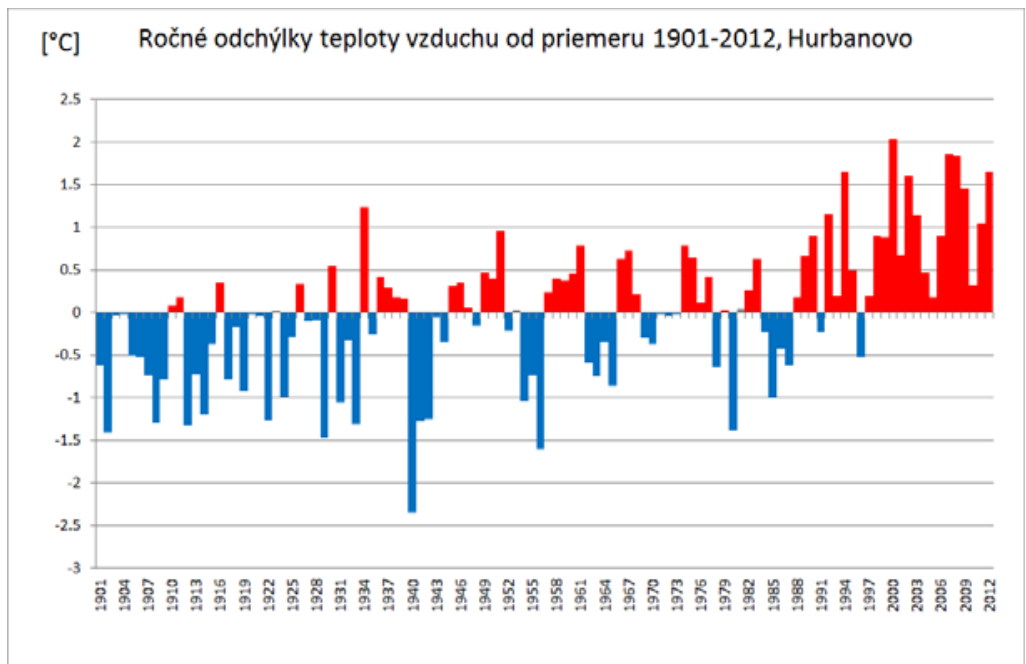

Fig. 1. Annual deviations of air temperature from the average 1901-2012, Hurbanovo Source: SHMU

Agriculture is considered the most vulnerable to global climate change, food security is another issue that requires the attention of all people, and the impact of climate change on agriculture is attracting a great deal of attention [8]. World agriculture is expected and required to produce food that will be able to feed a growing human population. However, demographic scenarios are uncertain and there are different development scenarios. Overall, however, it is a complex socio - economic issue, but it can be said that the future goal is to produce significantly more food while minimizing side effects, including excessive consumption of scarce water, pollution of the environment and agricultural products by agrochemicals and air pollution by greenhouse gases. Land use for food and biomass production is a source of emissions of significant greenhouse gases such as carbon dioxide, methane and nitrous oxide. At the same time, there are a number of options for reducing emissions. The most well-known mitigation measures include increased efficiency of crop production, increased efficiency of animal production, improved care for manure, improved food utilization and a lower proportion of animal proteins in the diet [9].

\subsection{Financial impacts of climate change}

Financial markets, actors, and instruments can contribute directly to ecosystem change inseveral ways. These direct connections are gaining an increased interest from policymakers atthe national and international level, and have spurred several global initiatives, 'green' financial innovations, as well as discussions about new financial risks of great importance for ecologists [10]. The change with the greatest impact on climate finance happened at the Copenhagen conference of the parties (COP) to the FCCC (United Nations Framework Convention on Climate Change) in December 2009. This meeting led to a fundamental shift in climate law as a whole, and in climate finance law in particular. From the ad hoc platform of legal principles to which climate law clung since the Rio Summit in 1992, states in Copenhagen moved climate law - and with it climate finance - onto a new, more coherent, and rational basis [11]. According to several studies examining the financial impact of climate change on various sectors, the economic cost until 2050 is estimated at 
32billion EUR per year in the event of flood consequences; EUR 1.5 billion per year for increased water supply costs; EUR 1.5 billion a year for the impact of climate change on agriculture. Studies focusing on forest fires predict an increase in frequency and extent, especially in southern Europe. Fires currently affect more than half a million hectares of forest each year. The estimated economic damage is EUR 1.5 billion per year. Studies estimate that the scale of fires in Europe could increase by $200 \%$ by 2080 due to climate change. Assuming a decline of 1\% per year, global GDP would represent $72 \%$ of current levels in 2050 and $43 \%$ of current levels in 2100 due to climate change alone (without considering the impact of raw material and energy peaks). The development of a small, open economy in Slovakia will be much more influenced by the development of the climate in Europe and in the world (the nature of economic openness will not change, because given the size of the economy in Slovakia we are forced to import most products). As in Slovakia, we can expect uneven changes on a global scale, which will allow some regions to prosper more and others less so. Slovakia is likely to be one of the least affected areas, with around $0 \%$ of GDP change and possibly a modest increase in GDP due to improved agricultural production [12].

\section{FIGURE 7 \\ IMPACTS OF CLIMATE CHANGE ON CROP YIELDS, AREA, PRODUCTION, PRICES AND TRADE BY 2050 AT THE GLOBAL LEVEL}

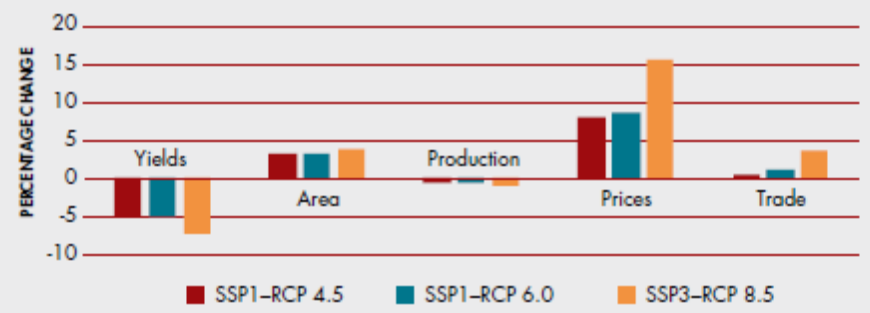

Notes: : Crops included are coarse grains, rice, wheot, oilseeds and sugar. See Box 7 for an explanation of RCPs and SSPs. SOURCE: Wiebe et al., 2015.

Fig. 2. Impact of climate change on crop yields,area,production,prices and tade by 2050 at the global level

Source: FAO

Climate change increases the risk and uncertainties offarming, at least in the context of many lower-incomecountries. It triggers changes in temperatures and rainfall,and makes the weather less predictable for farmers. This induces changes in the sowing and harvesting periods forcrops, often shortening the cropping season. In livestockproduction, climate change affects water and feed avail-ability as well as animal health. Thus climate change addsto financial stress and risk in agriculture [13].

Even without climate change, more investment is needed in the development of agricultural science and technology to meet the demands of the world's population, which should reach 9 billion by 2050. Many of these people will live in the developing world, have higher incomes and will crave food diversity. Solutions based on agricultural sciences and technologies are needed to meet these requirements. Climate change places new and more demanding demands on agricultural productivity. Research to support crop and livestock productivity, including biotechnology, will be needed to support overcoming climate change stress. There is a need for crops and livestock that thrive reasonably well in a variety of production environments, and not just in tight climates.. The results of the FAO study show that by 2050 , in relation to the world's climate change, global average crops of grains, rice, wheat, oilseeds and sugar beet will fall by 5 to 7 percent, while production areas will increase by about 4 
percent (Figure 2). The impact of climate change on overall production will be relatively small. However, production areas as well as basic food prices will increase to about twice the rate projected in 2006 with a significant impact on the environment and food security [14].

\subsection{Financing climate change}

Climate finance is defined in the United Nations Framework Convention on Climate Change (UNFCCC) as local, national or transnational funding drawn from public, private and alternative sources of funding that seek to support climate change mitigation and adaptation measures. These are investments that governments, corporations and households must make to move the world economy to a low-carbon path, to reduce greenhouse gas concentration levels and to increase countries' resilience to climate change. The European Commission estimates that investment in infrastructure, mainly from the private sector, would need to rise to $2.8 \%$ of the European Union's gross domestic product (GDP) from the current $2 \%$ today (or another $\$ 376$ billion a year) to reduce net greenhouse gas emissions in the EU to technical zeros by the middle of the century [15].

Climate finance is a subset of green finance and concerns the provision of funding specifically for climate change mitigation and adaptation activities, which include in particular public funding and the use of private finance in developing countries [16]. The authors' analysis [17] highlights previously underestimated economic costs of change in climate-sensitive developing economies. The results of the analysis suggest that companies in countries with a higher climate risk have higher financing costs and are significantly more financially limited. This has important implications for economic development: higher costs for financing companies and reduced economic growth and development, reduced tax revenues and a reduction in the size of governments seeking to make public investment. To keep the planet on a $2{ }^{\circ} \mathrm{C}$ trajectory, developing countries alone will require $\$ 500$ billion a year by 2030 to adequately reduce their carbon emissions, in addition to hundreds of other billions of dollars in adaptation needs. The $\$ 100$ billion a year pledged by developed countries through the Green Climate Fund is so insufficient that most of the climate funding needed will have to come from the private sector. The lack of trust and transparency in the global climate finance environment provides the basis for the deployment of Blockchain technology to awaken global climate finance flows [18]. Climate change financing refers to the financing of climate change-related activities. The UN Framework Convention on Climate Change has defined them as funding aimed at reducing emissions, reducing vulnerability and, conversely, increasing the resilience of human society as well as environmental systems to the negative effects of climate change. Climate change funding comes from international, national and regional actors. It includes supportive mechanisms for adaptation, such as mitigation to move to a low-carbon economy. Governments have a range of funding mechanisms and sources at their disposal. Within the EU, these are the Structural Funds, investment funds and the European Investment Bank. At the national level, then from state funds, state budgets and self-government. Other sources of funding are provided through cooperation between the private and public sectors. It is currently profitable for the private sector to invest in renewables-based infrastructure. The COVID-19 pandemic has demonstrably accelerated the need to examine mixed financial approaches [19]. The pandemic and the reactions to it are adversely affecting the agricultural sector, including capital flows, in particular access to key working capital for agricultural SMEs in emerging and emerging markets. Public investors should consider the immediate steps they can take to help facilitate access to working capital for vulnerable groups, as well as planning how to support the medium and long-term investments needed to rebuild agricultural-dependent economies. The pandemic is likely to place even greater emphasis on public sector budgets, which may increase the need for mixed financial solutions in the short and long term. The 
transition to sustainable agricultural systems is essential to meeting the global goals of sustainable development. Achieving more sustainable agricultural production systems will require a significant additional amount of capital, but this cannot cover the current organization of the financial market, which separates public and private financial institutions. Combined financing, which uses preferential development finance to mobilize additional private capital, is essential. To ensure the efficient and effective use of a limited amount of concession finance, a common understanding of the roles and constraints of public and private funding providers is needed. Given the limited scope of the published article and the wide variety of emerging information on climate change financing, we would mention two important sources in the article. The European Central Bank, as the monetary policy representative of the Eurozone, is currently actively involved in the design and financing of adaptation measures. The new coronavirus pandemic clearly demonstrates why central banks need to play a greater role in the fight against climate change, despite the fact that this issue has nothing to do with monetary policy at first sight, said Isabel Schnabel [20]. Executive Board member of the European Central Bank. Financial stability experts measure and evaluate the risks that climate change poses to the financial system. They shall inform the public, market participants and policy makers of their findings. The effects of climate change should be taken into account in monetary policy strategy in macroeconomic models, forecasting methods and risk assessments. In investment policy, the ECB engages in an asset purchase program mainly in the form of green bonds. The ECB also cooperates with commercial banks in the form of banking supervision and informs them about the risks posed by climate change. In terms of the use and possibility of using public resources, the reformed (2021 - 2027) Common Agricultural Policy is of great importance for the agricultural sector in the EU.

Table 1. The ECB 's monetary policy strategy

\begin{tabular}{|c|l|}
\hline \multicolumn{2}{|c|}{ The ECB 's monetary policy strategy } \\
\hline Economic analysis & $\begin{array}{l}\text { ECB staff ensure that climate change is taken into account in } \\
\text { the ECB's macroeconomic models, forecasting methods and } \\
\text { risk assessments. }\end{array}$ \\
\hline $\begin{array}{c}\text { Monetary policy and investment } \\
\text { portfolios }\end{array}$ & $\begin{array}{l}\text { In view of the need to prevent market distortions, the ECB } \\
\text { invests in so-called asset purchase programs. green bonds. }\end{array}$ \\
\hline Banking supervision & $\begin{array}{l}\text { Supervisors work with banks to raise awareness of the risks } \\
\text { posed by climate change. The aim is to ensure that banks are } \\
\text { able to adequately manage these risks. }\end{array}$ \\
\hline Financial stability & $\begin{array}{l}\text { Financial stability experts measure and evaluate the risks that } \\
\text { climate change poses to the financial system. They shall inform } \\
\text { the public, market participants and policy makers of their } \\
\text { findings. }\end{array}$ \\
\hline
\end{tabular}

Source: ECB

The common agricultural policy is one of the largest and longest-running agricultural policies in the world. It was originally aimed mainly at supporting production and agricultural incomes, and only gradually began to integrate instruments to support the environment. Nevertheless, the existing CAP is still not enough to tackle environmental degradation and climate change. $94 \%$ of the population and $64 \%$ of EU farmers agree with this view. Previous CAP reforms have been insufficiently transparent. In the process of the 2013 reform, the dominance of farmers' lobby groups led to the concept of re-expanding production, harmful subsidies and the weakening of targeted ambitious environmental tools (greening). The post2020 CAP proposal declares that it will address key societal challenges but is unlikely to improve its performance towards environmental economic and social sustainability and even risks spreading harmful subsidies. In 2018, the European Commission presented a proposal 
to reform the EU's Common Agricultural Policy (CAP) beyond 2020, which increases environmental ambitions. The EU's agricultural policy is set to be an important building block for the European Green Agreement, which will ensure that the Union is climate-neutral in 2050. Three of the nine key objectives of the CAP reform are to better protect the environment and the climate. The first objective is climate change measures, where the reformed CAP will contribute to the sector's adaptation to climate change, its mitigation and better use of energy from renewable sources. According to the European Environment Agency, agriculture and tillage account for 12 percent of EU greenhouse gas emissions. Climate change has several negative effects on agricultural production and is reflected in an increase in pests, drought, changes in the structure of precipitation, changes in soil diversity and increases in wind erosion. Problems with soil quality persist in Slovakia. More than a third of arable land is threatened by water and wind erosion. Soil erosion causes the removal of soil particles, the degradation of soil fertility and the loss of organic matter and nutrients. High tillage intensity, intensive fertilization and other inappropriate land uses cause carbon losses from the soil. Consumption of chemical pesticides in Slovakia has increased by $40 \%$ in the last eight years. Agriculture is the largest producer of ammonia in Slovakia from all sectors. It is formed in animal production and in the use of organic and chemical fertilizers. Therefore, in the second objective, the CAP will support the sustainable development and efficient management of natural resources such as soil, water and air. The third objective of the CAP will support the protection of biodiversity, the improvement of ecosystem services and the conservation of habitats and landscape areas. On average, Slovakia has the largest area of monocultural fields and fields in the EU with an average size of 12 hectares. Low crop diversity leads to a loss of biodiversity. Over the past 12 years, the abundance of some bird species has decreased by $32 \%$, and according to the results of continuous monitoring of habitats of European importance, in $201775 \%$ of habitat species were in an unfavorable condition. In the emerging green architecture of the CAP, Member States must determine, according to their needs (enhanced conditionality), the agricultural and environmental conditions that each farmer must meet in order to benefit from agro-subsidies. An example could be crop rotation or the allocation of part of the land to permanent grassland. Member States may encourage farmers to take the environment into account beyond the basic requirements. Ecosystems compensate for the loss of farmers who have voluntarily opted for practices that lead to environmental, climate, biodiversity and animal health protection. Agrienvironmental - climate measures are measures to protect the environment and climate from the Rural Development Program, ie agricultural Eurofunds. Member States are required to allocate at least $30 \%$ of the RDP budget to these measures. It can be an investment in renewable energy sources or in environmentally friendly technologies [21].

As much as $72 \%$ of the CAP budget currently goes to non-targeted direct payments, which are not linked to meeting CAP objectives. Several scientific studies evaluating the EU's Common Agricultural Policy from a socio-economic and environmental point of view point to a huge distortion in the distribution of first pillar subsidies (so-called direct payments) where $80 \%$ of payments are received by $20 \%$ of beneficiaries, and in terms of environmental payments those that are least effective. Apart from environmental aspects, direct payments are reflected in land prices, making it difficult for young and novice farmers to enter the sector. This system is not effective in ensuring a fair income for farmers either. It does not take into account how the land is used, the market situation and the total income of the farm. Last but not least, the current system is a breeding ground for various speculations. Direct payments are not efficient and the future could be a completely new financing system, where the payment will be linked to the creation of specific benefits for society. In such a system, the size of the farm is pointless and it is a way of guaranteeing a truly fair distribution of CAP funds within the EU. The European Commission announced in 2019 that the total budget for the agro-sector would be $€ 365$ billion, representing $28.5 \%$ of the total EU budget over the 
next seven years. Most of the amount, up to EUR 265.2 billion, is intended for the so-called direct payments, otherwise called agricultural subsidies. Up to EUR 20 billion will go to market support measures and EUR 78.8 billion has been earmarked for rural development. An additional EUR 10 billion will be available to support specific research and innovation in the areas of food, agriculture, rural development and the bioeconomy. Slovakia will receive almost EUR 4.4 billion in the agricultural sector between 2021-2027. Of Slovakia's EUR 4.388 billion, it will go to subsidies EUR 2.753 billion, EUR 41.2 million to support the market and EUR 1.593 billion to rural development. The reformed EU agricultural policy (2021-2027) should be fairer and more environmentally friendly, as well as innovationoriented. Member States will have a freer hand in how to use the funds allocated. Funding programs will be able to adapt to their own needs under the supervision of the European Commission. States will be able to transfer $15 \%$ of allocations from direct payments to rural development and vice versa. Slovakia is currently using the opposite option to increase direct payments of money that would otherwise go to rural development projects. Agro-policy should be fairer in prioritizing small and medium-sized agribusinesses, which make up the majority of the EU's agricultural sector, and helping young farmers. Small and medium-sized agricultural holdings will receive higher support per hectare and Member States will have to set aside at least $2 \%$ of direct payments to help young farmers start-up. Direct payments will also be conditional on increased environmental and climate requirements. At least $30 \%$ of each national rural development allocation should go to green measures.

In addition to the possibility to transfer $15 \%$ between the pillars (direct payments / rural development), Member States will be able to transfer a further $15 \%$ from the first to the second pillar for expenditure on climate and environmental measures. Direct payments should increasingly deviate from entitlements determined on the basis of historical criteria and, conversely, take into account activities that bring additional social, environmental or other benefits to the public.

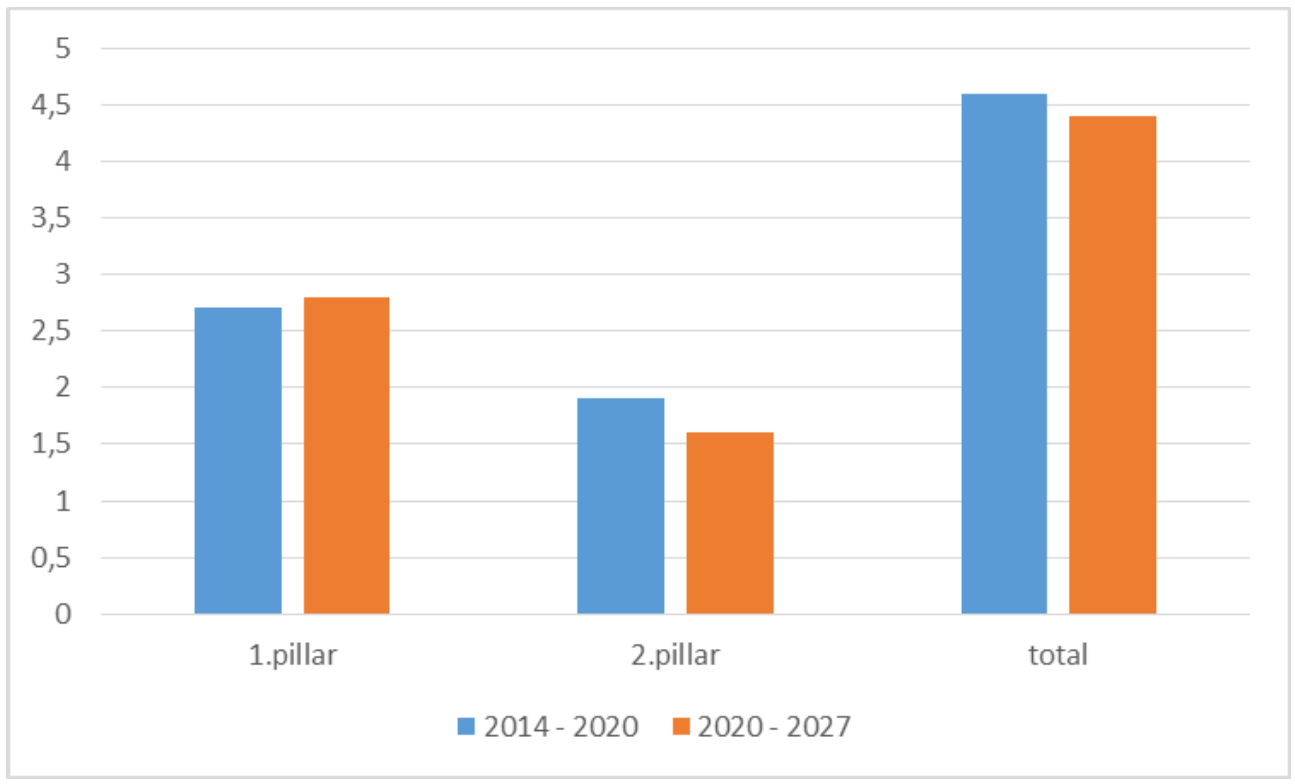

Fig. 3. CAP in Slovakia in billions of EUR

Source: own data

\section{Conclusion}


The effects of climate change are also felt in the Slovak Republic. Climate change is a challenge for the primary agricultural sector. The agricultural sector has a historical responsibility and should respond urgently to climate phenomena and seek solutions to adapt to climate change. Farmers, as agents of change, must be prepared and motivated to accept them. Adaptation of agriculture in the Slovak Republic to climate change presupposes fundamental changes in the management of agricultural production such as consistent application of the principles of good agricultural practice (Act 220/2004 Coll., Code of good agricultural practice), proper fertilization in terms of nutrient regime in terms of principles of proper use of fertilizers, changes in plant nutrition, expansion of green fertilization, changes in agroclimatic zoning changes, in crop technology, revitalization of existing and construction of new irrigation facilities, securing and maintaining favorable soil moisture, restoration and reconstruction of multifunctional and ecologically stabilized agricultural land, reduction of agricultural area areas used, compliance with anti-erosion and other soil protection measures, efforts to increase the accumulation of carbon in the soil and others [22].Agriculture will be exposed to the expected negative consequences of climate change: changes in species composition, number and location of pests (diseases, pests, weeds), but especially in an increase in economically important pests, changes in temperature of crop production, changes in phenological conditions and agroclimatic production. potential, changes in the distribution and amount of precipitation and humidity, changes in wintering conditions (absence of snow cover), changes in soil diversity and physical and chemical properties of the soil, increased wind erosion, complete change or loss of crop production, especially due to drought. However, climate change will bring not only negative effects but also positive effects on agriculture such as increased plant photosynthesis and biomass growth due to increased $\mathrm{CO} 2$ concentrations in the atmosphere depending on water availability, shifting production areas in favor of more northern regions of Slovakia, growing new thermophilic crops and extending (Apart from adaptation measures, the basic measure is the realization of income from agricultural production, setting goals and linking them to the new CAP and domestic budget, development of tourism in rural areas, creation of positive externalities, landscaping and non-productive functions of agriculture. The possibilities for financing adaptation measures are diverse, coming from private and public sources.

This paper was supported by the project VEGA no. 1/0338/18 with the title Impact of the Common Agricultural Policy on the mitigation of income risk in Slovak agriculture and factors determining the level of risk of agricultural companies.

\section{References}

1. Lisý, J. (2005). Ekonómia v novej ekonomike. IURA Edition.

2. Taheri, H. and P. Taheri. (1964). Globalization and its dimensions. Kaboudrahang Press of Jam Jamshid.

3. Hepburn, C. (2010), Environmental policy, government, and the marke. Oxford Review of Economic Policy, 26 (2), 1-2.

4. THE 17 GOALS. (FAO 2015). Department of Economic and Social Affairs Sustainable Development . Retrieved from: https://sdgs.un.org/goals

5. Hajer, M., Nilsson, M., Raworth, K., Bakker, P., Berkhout, F., De Boer, Y., Rockstrom, J., Kathrin, L., Kok, M. (2015). Beyond Cockpitism: Four Insights to Enhance the Transformative Potential of the Sustainable Development Goals. Sustainability, 7(2), 1351-1660. 
6. Bauhardt, Ch. (2014). Solutions to the crisis? The Green New Deal, Degrowth, and the Solidarity Economy: Alternatives to the capitalist growth economy from an ecofeminist economics perspective. Ecological Economics, 102, 60-68.

7. Capasso, M., Hansen, T., Heiberg, P., Klitkou, A., Steen, M. (2019). Green growth - A synthesis of scientific findings. Technological Forecasting \& Social Change, 146, 390402.

8. Jinxia, W., Hjikun, H., Yang, H. (2017). Overview of Impacts of Climate Change and Adaptation in China's Agricultur., Journal of Integrative Agriculture, 13(1), 1-17.

9. Šimek, M. (2019). Skleníkové plyny z pudy a zemědelství - vlastnosti, produkce, spotřeba, emise a možnosti jejich snížení. Akademie věd české republiky Strategie AV, 21,131 .

10. Galaz, V., Gars, J., Moberg, F., Nykvist, B., Repinski, C. (2015). Why Ecologists Should Care about Financial Markets. Trends in Ecology \& Evolution, 30(10), 572.

11. Zahar, A. (2017). Climate Change Finance and International Law. Abingdon, Oxon; New York, NY : Routledge.

12. Stanek, P., Doliak, D., Ivanova, P. (2017). Globálne zdroje hrozba alebo šanca? Wolters Kluwer, Edícia Ekonómia, 51.

13. Oostendorp, R., Asseldonk, M., Gathiaka, J., Mulwa, R., Radeny, M., Recha, J., Wattei, C., Wesenbeeck, L. (2019). Inclusive agribusiness under climate change: a briefreview of the role of financ. Environmental Sustainability, 41, 18-22.

14. FAO - Food and Agriculture Organization of the United Nations (2016). The State of Food and AGRICULTURE Climate Change, Agriculture and Food Security.

15. Hong, H., Karolyi, A., Scheinknian, J. A. (2020). Climate Finance. ,Review of Financial Studies, 101.

16. Wareen, P. (2020). Blind spots in climate finance for innovation. Advances in Climate Change Research, 11(1), 60-64.

17. Kling, G., Volz, U.(2020). The impact of climate vulnerability on firms' cost of capital and access to finance, World Development, 137,60 .

18. Marke, A., Sylvester.B. (2018). Decoding the Current Global Climate Finance Architecture. Transforming Climate Finance and Green Investment with Blockchains, 35-59.

19. Havemann, T., Negra, C., Werneck, F.(2020). Blended finance for agriculture: exploring the constraints and possibilities of combining financial instruments for sustainable transitions. Agriculture and Human Values, 37, 1281 -1292.

20. Trend (2020). Členka výkonnej rady ECB: Klimatická zmena je väčším rizikom než pandémia. Retrieved from: https://www.trend.sk/spravy/clenka-vykonnej-rady-ecbklimaticka-zmena-je-vacsim-rizikom-nez-pandemia

21. Drapáková, D.,Koreň, M.(2020). Nová zelená architektúra Spoločnej polnohospodárskej politiky EÚ. Retrieved from: www. euractiv.sk,

22. Sobocká, J. (2005). Possible Consequences of Climate Change on Soil Properties of the SR. Životné prostredie, 39(4) ,182-186. 